\title{
ANALISIS STRUKTUR DAN CIRI KEBAHASAAN TEKS ULASAN FILM DI GOOGLE SERTA PEMANFAATANNYA SEBAGAI BAHAN AJAR UNTUK SMP KELAS VIII
}

\author{
Iin Parlina ${ }^{1)}$ Eka Wahyuni ${ }^{2)}$ \\ 1) 2) Program Studi Pendidikan Bahasa Indonesia \\ Universitas Islam Ogan Komering Ilir Kayuagung \\ 1) parlina.ok0303@gmail.com ${ }^{2}$ ekawahyuni5815@gmail.com
}

\begin{abstract}
Abstrak
Penelitian ini bertujuan mendeskripsikan (1) struktur teks ulasan film dari google; (2) ciri kebahasaan teks ulasan film; dan (3) pemanfaatan sebagai bahan ajar tentang struktur dan ciri kebahasaan teks ulasan di SMP kelas VIII. Penelitian ini berjenis deskriptif kualitatif menggunakan pendekatan analisis isi (Content Analysis). Data dikumpulkan dengan teknik dokumentasi. Hasil penelitian dari 25 teks ulasan ditemukan 11 teks yang memiliki pemaparan argument lebih dari satu. Selanjutmya, ciri kebahasaan teks ulasan film, yang paling dominan adalah penggunaan opini. Ciri kebahasaan yang sedang adalah penggunaan kata kerja kopulatif. Terdapat 24 teks yang menggunakan kata kerja tersebut. Sementara itu, ciri kebahasaan yang paling sedikit adalah penggunaan ungkapan perbandingan. Terdapat 8 teks yang menggunakan ciri tersebut; (3) berdasarkan hasil analisis struktur dan ciri kebahasaan teks ulasan film. Hasil analisis dapat dijadikan sebagai bahan ajar tentang struktur dan ciri kebahasaan teks ulasan yang termuat pada silabus.
\end{abstract}

Kata kunci: bahan ajar, ciri kebahasaan, struktur teks, teks ulasan film

\section{PENDAHULUAN}

Dalam K.13, khususnya di materi bahasa Indonesia berorientasi pada pembelajaran berbasis teks. Bertujuan supaya peserta didik bukan hanya memiliki kognitif saja, tetapi diprioritaskan banyak membaca dalam menelaah arti teks yang didapatkan. Mereka diperkenalkan aturan-aturan yang relevan agar proses penerimaan informasi sesuai yang diharapkan oleh guru. Seperti tercantum dalam kompetensi dasar substansi bahasa Indonesia dari pendidikan dasar, menengah, sampai perguruan tinggi (Mahsun, 2014:94).

Pembelajaran berbasis teks ialah hal yang dianggap baru dan pondasi awal. Pilihan pada pembelajaran membawa implikasi metodologis pada pembelajaran berkesinambungan. Dimulai kegiatan pengajar membangun konteks, sampai pemodelan, membangun teks secara bersama-sama, 
mengidentifikasi struktur pembangun teks, sampai pada membangun teks secara mandiri. Dilakukan karena teks merupakan satuan bahasa yang terkandung pemikiran struktur yang kompleks

Salah satu teks dalam kurikulum 2013 edisi revisi bahasa Indonesia tingkat SMP kelas VIII. Dalam proses belajar mengajar, siswa kelas VIII menerima materi teks yang ada di genap sesuai KD 3.12, yaitu menelaah struktur dan kebahasaan teks ulasan (film, cerpen, puisi, novel,) diperdengarkan dan dibaca. Dalam penelitian ini peneliti hanya berfokus pada teks ulasan film saja.

Teks ulasan film termasuk hasil penafsiran terhadap pementasan film tertentu. Pembaca atau penyimak mudah saat memahami tayangan, dengan sinopsis mengetahui isi, serta ketika membaca analisis semua orang menjadi tahu struktur tayangan tersebut, bahkan kelebihan dan kelemahan (Kosasih, 2014:204). Selain itu, teks ulasan film mengajarkan siswa untuk menguasai permasalahan yang dikritik, mengetahui kelengkapan struktur teks, serta dapat memberikan solusi terhadap persoalan yang dirasakan (Kemendikbud, 2013:51).

Kosasih (2014:206) menguraikan biasanya teks ulasan memiliki struktur berikut ini.

1. Mengetahui isi atau tinjauan karya yang ada didalamnya berupa judul, sutradara, para pemain, sinopsis dalam cerita.

2. Penguraian pendapat di bagian inti teks, berisi analisis unsur karya berdasarkan perspektif tertentu. Poin ini mengemukakan fakta tambahan untuk memperkuat yang menulis ataupun si pembicara.

3. Menilai dan merekomendasikan, berupa pertimbangan keunggulan dan kelemahan film yang diulas. Terdapat saran-saran untuk khalayak terkait dengan kepentingan apresiator.

Berdasarkan ciri kebahasaan, teks ulasan memaparkan pendapat suatu karya yang diobservasi maupun dianalisis. Berisi komentar, pendapat, dan amanat yang disampaikan kepada penulis agar karya berikutnya lebih baik, sehingga berguna bagi pencinta karya sastra. Masih pendapat Kosasih (2014:97) 
ciri kebahasaan teks ulasan diuraikan berikut.

1. Teks ulasan film menonjolkan unsur-unsur karya seni yang akan diulas.

2. Penggunaan opini, contohnya pada kalimat: inilah film Indonesia yang patut untuk ditonton.

3. Menggunakan konjungsi internal dan konjungsi eksternal,

1) Konjungsi internal (intrakalimat), konjungsi menghubungkan dua argumen/gagasan/ide dalam kalimat. Terdapat 4 (empat) kategori makna hubungan seperti, penambahan/kesejajaran, menyatakan waktu, menyatakan perbandingan, menyatakan sebab-akibat

2) Konjungsi eksternal (antarkalimat), konjungsi yang menghubungkan dua peristiwa/deskripsi hal/benda dalam kalimat. Konjungsi ini juga dibedakan atas 4 kategori makna hubungan yakni, penambahan/kesejajaran, mencirikan waktu/temporal, menunjukkan perbandingan

$$
\begin{array}{lr}
\text { 4. Menguraikan } & \text { sebab-akibat, } \\
\text { menggunakan } & \text { ungkapan } \\
\text { perbandingan } &
\end{array}
$$

5. Penggunaan kata kerja

\section{METODE PENELITIAN}

Pendekatan yang digunakan ialah analisis isi, sedangkan metode yang diterapkan metode kualitatif bersifat deskriptif. Sumber data pada penelitian ini berupa dua puluh lima teks ulasan film dari media elektronik google. Teks ulasan film ini merupakan teks ulasan dengan judul yang berbeda. Teknik analisis data yang dilakukan yakni, mengidentifikasi data dari 25 teks ulasan film dalam media elektronik google, mengklasifikasikan gambaran megenai struktur dan ciri kebahasaan yang membangun teks ulasan film, menganalisis, menginterpretasi, mendeskripsikan pemanfaatan hasil analisis sebagai bahan ajar SMP kelas VIII sesuai dengan kompetensi dasar pada kurikulum 2013 KD 3.12, terakhir menyimpulkan data. 
PEMBAHASAN

Tabel 1 Data Rekapitulasi Analisis Struktur dan Ciri Kebahasaan dalam Teks Ulasan Film dari Google

\begin{tabular}{lll}
\hline $\begin{array}{l}\text { Komponen Aspek } \\
\text { Struktur Teks }\end{array}$ & \multicolumn{1}{c}{ Hasil Analisis } \\
\hline $\begin{array}{l}\text { 1. Pengenalan Isi atau } \\
\text { Tinjauan Karya }\end{array}$ & 1) $\begin{array}{l}\text { Keduapuluh Lima teks ulasan film memiliki } \\
\text { bagian pengenalan isi atau tinjauan karya }\end{array}$ \\
& 2) $\begin{array}{l}\text { Terdiri atas 4-6 paragraf } \\
\text { 3) }\end{array}$ \\
& $\begin{array}{l}\text { Secara singkat menceritakan gambaran awal } \\
\text { cerita berupa identitas karya, nama tokoh, awal } \\
\text { mula penayangan film,dan kondisi sosial pemain } \\
\text { dalam film }\end{array}$ \\
& 4) $\begin{array}{l}\text { Pengenalan kehidupan tokoh utama, watak tokoh, } \\
\text { dan kebiasaan umum yang ada dalam teks. }\end{array}$ \\
& 1) $\begin{array}{l}\text { Terdapat 11 teks ulasan film yang memiliki lebih } \\
\text { dari satu pemaparan argument }\end{array}$ \\
2. Pemaparan & 2) $\begin{array}{l}\text { Penjelasan singkat munculnya sebab-akibat } \\
\text { Argument }\end{array}$ & 3) Tokoh utama menemui permasalahan \\
& 4) Pernyataan pendapat terkait karya yang diulas \\
& 1) $\begin{array}{l}\text { Keduapuluh Lima teks ulasan film memiliki } \\
\text { penilaian }\end{array}$ \\
3. Penilaian dan & 2) $\begin{array}{l}\text { Berisi sebuah penilaian berupa kelebihan dan } \\
\text { kekurangan dari karya yang diulas }\end{array}$ \\
Rekomendasi & 3) Berisi sebuah saran
\end{tabular}

Ciri Kebahasaan

1. Penonjolan Terhadap Unsur Karya Seni

2. Penggunaan Katakata Opini

3. Penggunaan Konjungsi Internal dan Konjungsi Eksternal

4. Penggunaan Ungkapan Perbandingan

5. Penggunaan Kata Kerja (kata kerja material, kata kerja
Terdapat tiga teks ulasan film yang tidak memiliki penonjolan terhadap unsur karya seni

Keduapuluh lima teks ulasan film menggunakan kata-kata opini

1) Konjungsi internal (dan, atau, serta, sejak, setelah,saat, tetapi, sedangkan, sebab-akibat, sehingga, karena)

2) Konjungsi eskternal (selain itu, awalnya, lalu kemudian, akhirnya, akan tetapi, sementara itu, namun, walaupun, oleh karena itu, akibatnya)

3) Terdapat 5 teks ulasan film yang tidak menggunakan konjungsi eksternal

Terdapat 17 teks ulasan film yang tidak menggunakan ungkapan perbandingan

1) Kata kerja material (43 kalimat)

2) Terdapat 6 teks ulasan yang tidak menggunakan kata kerja material 
relasional, dan kata

kerja kopulatif)
3) Kata kerja relasional (16 kalimat)

4) Terdapat 14 teks yang tidak menggunakan kata kerja relasional

5) Kata kerja kopulatif (54 kalimat)

6) Terdapat 1 teks yang tidak menggunakan kata kerja kopulatif
Pemanfaatan Teks Ulasan Film Bahan Ajar SMP Kelas VIII

Berdasarkan hasil analisis struktur dan ciri kebahasaan dalam 25 teks ulasan film dari media elektronik google, hasil penelitian ini dapat dimanfaatkan sebagai materi pembelajaran dalam silabus bahasa Indonesia SMP kelas VIII semester 2 kurikulum 2013. Mata pelajaran wajib yang tertuang dalam kompetensi Inti 3 (KI-3) dan KD. 3.12 menelaah struktur dan ciri kebahasaan teks ulasan (film, cerpen, puisi, novel, karya seni daerah yang diperdengarkan dan dibaca). Kedua, hasil dari penelitian ini nantinya dapat digunakan untuk mengembangkan dan menghasilkan produk penelitian dengan metode (R\&D). Sugiyono (2008:15) berpendapat bahwa $R \& D$ adalah metode yang digunakan untuk menghasilkan produk, dengan cara menguji keaktifan suatu temuan. Dengan demikian, melalui hasil analisis 25 teks ulasan film dari media elektronik google dapat digunakan dan dikembangkan menjadi produk bahan ajar supaya meningkatkan kualitas pendidikan khususnya pengembangan bahan ajar teks ulasan lebih lanjut.

\section{SIMPULAN}

Keduapuluh lima judul teks terdapat mempunyai struktur yang utuh apabila dilihat dari struktur pengenalan isi atau tinjauan karya. Kemudian pada struktur pemaparan argument terdapat 12 judul yang memiliki struktur pemaparan argument lebih dari satu, selebihnya 13 judul lainnya memiliki satu pemaparan argument. Berikutnya struktur penilaian dan rekomendasi, dari kedua puluh lima teks ulasan film yang dianalisis seluruh teks memiliki penilaian rekomendasi.

Hasil analisis ciri kebahasaan, dari kedua puluh lima teks ulasan film yang dianalisis ada 2 judul yang 
tidak memiliki penonjolan terhadap unsur karya seni. 25 teks ulasan film memiliki ciri kebahasaan yang utuh apabila dilihat dari penggunaan opini. Kemudian ciri kebahasaan terkait penggunaan konjungsi internal dan eksternal, 25 teks ulasan menggunakan konjungsi internal, namun terdapat 4 judul yang tidak memiliki konjungsi.

Dari hasil analisis yang peneliti peroleh dapat disimpulkan bahwa hasil analisis bisa dimanfaatkan sebagai bahan ajar tentang struktur dan ciri kebahasaan teks ulasan untuk menunjang keberhasilan dan pencapaian tujuan pembelajaran.

\section{SARAN}

Penulis memberikan saran bagi guru bahasa Indonesia sebaiknya dalam melaksanakan pembelajaran guru tidak hanya fokus pada buku paket yang diberikan oleh pemerintah sebagai sarana penunjang pembelajaran karena buku tersebut memiliki keterbatasan. Selain itu, penelitian ini masih terbatas, karena peneliti hanya mendeskripsikan susunan dan kekhasan teks ulasan film.

\section{DAFTAR PUSTAKA}

Kemendikbud. (2013). Permendikbud No.81a tentang implementasi kurikulum. Jakarta: Kementrian Pendidikan dan Kebudayaan

Kosasih, E. (2014). Jenis-jenis teks. analisis fungsi, struktur, dan kaidah serta langkah penulisannya. Bandung: Yrama Wijaya

Mahsun. (2014). Teks dalam pembelajaran bahasa indonesia kurikulum 2013. Jakarta: Grafindo Persada

Mahsun. (2018). Teks dalam pembelajaran bahasa indonesia kurikulum 2013. Depok: Raja Grafindo Persada 